\title{
Circadian Rhythms and Measures of CNS/Autonomic Interaction
}

\author{
Francesco Riganello ${ }^{1}$, Valeria Prada ${ }^{2}$, Andres Soddu ${ }^{3}$, Carol di Perri ${ }^{1,4}$ and Walter G. Sannita ${ }^{2, *}$ \\ 1 Coma Science Group, GIGA-Consciousness, GIGA Institute, University Hospital of Liège, \\ 4000 Liège, Belgium \\ 2 Department of Neuroscience, Rehabilitation, Ophthalmology, Genetics and Maternal/Child Sciences, \\ University of Genova, Polyclinic Hospital San Martino IRCCS, 16132 Genova, Italy \\ 3 Department of Physics and Astronomy, Brain and Mind Institute, The University of Western Ontario, \\ London, ON N6A 3K7, Canada \\ 4 Centre for Clinical Brain Sciences, The University of Edinburgh, Edinburgh, EH16 4SB, UK \\ * Correspondence: wgs@dism.unige.it; Tel.: +39-010-3537464 or +39-335-6248331
}

Received: 21 May 2019; Accepted: 27 June 2019; Published: 2 July 2019

\begin{abstract}
The physiological role and relevance of the mechanisms sustaining circadian rhythms have been acknowledged. Abnormalities of the circadian and/or sleep-wakefulness cycles can result in major metabolic disorders or behavioral/professional inadequacies and stand as independent risk factors for metabolic, psychiatric, and cerebrovascular disorders and early markers of disease. Neuroimaging and clinical evidence have documented functional interactions between autonomic (ANS) and CNS structures that are described by a concept model (Central Autonomic Network) based on the brain-heart two-way interplay. The circadian rhythms of autonomic function, ANS-mediated processes, and ANS/CNS interaction appear to be sources of variability adding to a variety of environmental factors, and may become crucial when considering the ANS major role in internal environment constancy and adaptation that are fundamental to homeostasis. The CNS/ANS interaction has not yet obtained full attention and systematic investigation remains overdue.
\end{abstract}

Keywords: circadian rhythms; sleep-wakefulness cycle; autonomic system; central/autonomic systems interaction; HRV; heart rate variability

\section{Introduction}

Circadian rhythms are governed by a biological master clock (synchronized on the fluctuations in light intensity and temperature) and by intrinsically cyclic clock genes regulated by the hormonal status and environmental factors. This arrangement controls metabolism, endocrine secretion, cardiovascular and motor activity, and the sleep-wakefulness cycle of light-sensitive organisms, thus guaranteeing homeostatic constancy, efficiency of physiological processes, and the adaptation to internal/external changes and requirements [1-12]. The suprachiasmatic nuclei (SCN) serve as the central pacemaker driven by information from the retino-hypothalamic tract and by signals from neuronal networks and molecules selectively crossing the blood-brain barrier [4,13-16]. Adaptation and behavior are influenced by the SCN via neuronal and neuroendocrine cues and synchronization of the peripheral clocks in organs and tissues $[17,18]$ that also integrate information from the environment to coordinate appropriate responses [19]. The circadian system sets time windows, particularly in the alternation of sleep and wakefulness, that often reach pathophysiological relevance [20-23]. There is full evidence of a complex interaction between the central (CNS) and autonomic (ANS) nervous systems, with a two-way modulation of, and by, circadian rhythms. 


\section{Circadian Rhythms and Hypothalamic Control}

The hypothalamus is a key target of SCN and the core structure complying with circadian variations in the control of sleep/wakefulness alternation and hormone release, as well as in the regulation of food intake and liver, pancreas, kidney, and heart function [5,6,8,10,24-27]. A major input to the hypothalamus is about light/dark conditions and temperature. The retinal ganglion cells innervating the SCN are intrinsically light sensitive and mediate in the circadian response to light via melanopsin and through cells in the periventricular hypothalamus and ventral thalamus that are selectively excited or inhibited depending on melanopsin activity [28-30]. The hypothalamus also modulates the sensitivity of target endocrine organs for pituitary hormones via its effects on the ANS [31]. The input to hypothalamus regarding temperature is less clear. The first relay nucleus appears localized in the dorsomedial hypothalamic nucleus (DMH) transferring information to the main hypothalamic regulator medial preoptic area (MPA) [32,33]. MPA is also influenced by feeding, metabolism, hormones, inflammation and the time of day, olfactory information from the nucleus of the solitary tract (NTS) and olfactory bulb that trigger an increase in temperature in postprandial time $[25,34-36]$.

\section{Circadian Rhythms and Sleep}

The circadian sleep/wakefulness alternation is driven by the SCN, which is reset by light and by melatonin secretion at night $[37,38]$. Neural networks in the brainstem, hypothalamus, and basal forebrain that selectively activate the cerebral cortex and thalamus are involved. These neurons are inhibited during sleep by GABAergic mechanisms in which the ventrolateral preoptic nucleus (VLPO) seems to have a key role [26]. Galanin- and GABAergic VLPO neurons project during sleep to the hypothalamic and the brainstem nuclei mediating in arousal [39-42]. VLPO is also important in REM sleep gating via projections on locus coeruleus and dorsal raphe, as well as by histaminergic innervation [43-46]. Wakefulness is sustained by the ascending arousal system, with the ascending pathway activating the thalamic relays (crucial in information transmission to cerebral cortex) [47] and the lateral hypothalamic area and basal forebrain projecting to the cerebral cortex [48-50]. In the first branch, the peduncolopontine and lateral-dorsal tegmental nuclei (PPT/LDT) (cholinergic) provide the main input from the upper brainstem to thalamic-relay nuclei and the reticular nucleus of thalamus [47]. The second branch originates from monoaminergic neurons in the upper brainstem and caudal hypothalamus, including histaminergic tuberomammillary neurons dopaminergic ventral periaqueductal grey matter, locus coeruleus, and raphe nuclei $[48,50]$. Most of the SCN output projects to the subparaventricular zone (SPZ) and dorsal medial nucleus of the hypothalamus (DMH). The SPZ amplifies the SCN output and projects in the DMH, which in turn mediates in the SCN-controlled sleep-wakefulness regulatory system and projects to VLPO and orexin neurons (orexin is a neuropeptide also known as hypocretin, that regulate arousal, wakefulness and appetite) [51-56]. DMH projects to VLPO, LC, and orexin neurons in the lateral hypothalamus [52]. Links between SCN and LC (including $\mathrm{DMH}$, paraventricular hypothalamic nuclei (PVN) and medial and ventrolateral pre-optic areas) are proposed and would confirm the role of the DMH relays in this circuit [52,57]. The selective lesion of DMH suppresses circadian changes in LC activity and reduces circadian rhythms [52,57].

\section{Circadian Rhythms, Sleep, Homeostasis, and Allostasis}

Sleep homeostatic adaptation is described by the accumulation of a need to sleep during prolonged wakefulness, with the NREM sleep and REM sleep being regulated by different homeostatic mechanisms possibly mediated for by adenosine [58-61]. Depletion of adenosine triphosphate and its degradation into adenosine diphosphate and monophosphate results in prolonged wakefulness together with exhaustion of brain glycogen [60]; adenosine activates the VLPO to trigger a sleep episode [59]. The homeostatic and circadian drive for sleep can be temporarily compensated for (as can be the case in emergencies) by shifting to a condition of allostasis (i.e., relative stability during adaptive 
variation, or in response to a challenge) [62]) through inputs to SNC, VLPO, and orexin neurons from corticolimbic sites (infralimbic cortex, ventral subiculum, lateral septum, and bed nucleus of stria terminalis) $[63,64]$.

\section{Circadian Rhythms and Age}

The SCN clock develops and is responsive to light early in gestation; the retino-hypothalamic tract is identifiable in 36-week human newborns and an effect of the mother's melatonin is suggested [28-30,65]. The day-night cycle in hormone secretion develops between 1 and 3 months, with cyclic cortisol production already at 6 weeks and rhythmical secretion of melatonin beginning at 6 to 12 weeks. The mature core body temperature rhythm and peripheral histone gene expression $\mathrm{H} 3 \mathrm{f} 3 \mathrm{~b}$ (an indicator of clock function) appear at 6 to 16 weeks; a fully developed circadian rhythm emerges 3 months after full-term birth with maturation of the nocturnal sleep organization; at around 9 months REM sleep decreases and NREM sleep increases during extensive networks remodeling as to dendritic arborization, synaptogenesis, myelinization, neurotransmitter development and programmed cell death. The interactions between brainstem and the thalamic and cortical structures increases [66-69].

Physiological aging is associated with significant changes in sleep, with a robust tendency toward an evening chronotype. The alignment between sleep and the circadian phase is progressively lost with aging; the circadian phase advances, the circadian rhythm amplitude is reduced, and its period shortened. In the absence of sleep disorders, the circadian markers of the sleep-wakefulness cycle (sleep onset and offset), melatonin (onset), core body temperature (acrophase), and cortisol (acrophase) indicate anticipation of sleep compared to young adults, with earlier bedtime and wake-up. Orexin neurons and their projections appear altered and orexin expression declines with aging [70]. Animal studies agree in indicating that the activity of SCN nuclei governing the circadian system is reduced with aging and the clock gene expression is altered, with age-related degradation at the network level and a decreased effectiveness of peripheral oscillators [71-73]. The SCN neuronal population is reportedly unchanged with aging, but significantly fewer vasopressinergic cells are involved in the downstream signaling in elderly rats [73]. Disordered sleep is common among the elderly, who in general report less total sleep time, poorer sleep efficiency, frequent awaking at night, excessive sleepiness during the day, and poor sleep adaptation to adverse circadian phases and sleep-wakefulness misalignment [74-79]. The effects of aging on the circadian organization and on each of the CNS and ANS functions conceivably outsize those on CNS/ANS balance, which remains poorly investigated. The time disarrangement over the $24 \mathrm{hrs}$. between the circadian rhythms (particularly the sleep-wakefulness cycle) and the daily activities impairs physiological adaptation $[80,81]$ to e.g., occasionally increase the incidence (with peaks in morning hours) of severe adverse cardiovascular events such as myocardial infarction, sudden cardiac death, or stroke [82].

\section{CNS/ANS Interaction and the Central Autonomic Network}

Heart rate, respiration, hormone secretion and transport to receptors, smooth muscles activity, and biological sensors are governed by the autonomic nervous system in the process of maintaining homeostatic balance [83]. ANS is also involved in the regulation of innate immune responses and inflammation through neuroendocrine mechanisms and qualifies as a centrally integrated neural reflex $[84,85]$. The sympathetic (fight or flight) and parasympathetic (rest and digest) ANS subsystems can act independently or antagonistically, e.g., in modulating the functional balance through inputs from thermoregulation, baroreceptors, chemoreceptors, renin-angiotensin-aldosterone, and atrial and ventricular receptors [86-90]. The functional CNS/ANS interaction involves the brainstem solitary tract nucleus and forebrain structures such as the anterior cingulate, insula, ventromedial prefrontal cortex, amygdala, and hypothalamus with bidirectional interactions between rostral and caudal systems. Parabrachial nucleus/locus coeruleus, cerebellum, periaqueductal gray, hypothalamus, amygdala, and insular and dorsomedial prefrontal cortices structures were found to interact in animal research and human fMRI studies. Some brain regions (dorsolateral prefrontal cortex, mediodorsal thalamus, 
hippocampus, caudate, septal nucleus, and middle temporal gyrus) have been proposed as possibly unique to humans $[51,83,91-97]$.

Neural structures and heart function also appear to be peculiarly linked in affective, "cognitive" and autonomic modulation [94,98,99]. A concept model (the Central Autonomic Network; CAN) has been proposed to describe the brain-heart two way interaction $[94,96,99]$. Several CNS structures are integrated in this model. In particular, the insular cortex, ventromedial prefrontal cortex, anterior cingulate cortex, and amygdala contribute to the modulation of cardiac sympathetic/ parasympathetic outflow. These stractues allow the integration of cardiovascular responses related to behavior and emotion through the hypothalamic area, the parabrachial region of the dorsolateral pons, nucleus of the solitary tract, nucleus ambiguous, rostral ventrolateral medulla, and intermediolateral cell columns $[96,98]$. The medial prefrontal cortex projecting to interconnected limbic cortical regions and subcortical nuclei (insula, medial temporal lobes, amygdala, ventral striatum, ventral caudate and putamen, mediodorsal thalamus, and hypothalamus) is thought to be a key structure in the brain control of cardiovascular responses [100-102].

Heart rate variability metrics (HRV) reflect the complex interaction between brain and the cardiovascular system and describes the ANS functional setup; evidence suggests these measures also reflect (to some extent and indirectly) higher brain functions, and are reliable independent indicators of CNS/ANS interaction $[83,97,103-108]$. HRV, the physiological variation in time of the interval between consecutive heartbeats, is analyzed in the time domain or frequency domains and by non-linear approaches $[83,108,109]$. The standard deviation of the EKG averaged RR interval reflects the contribution of both the sympathetic and parasympathetic system, while the root mean square is related to the parasympathetic activity. ANS functional contributions can be differentiated by analyses in the frequency domain, usually in three frequency bands: high frequency (HF) $(0.15-0.5 \mathrm{~Hz})$, low frequency (LF) $(0.04-0.15 \mathrm{~Hz})$, and very low frequency $(0.0033-0.04 \mathrm{~Hz})(\mathrm{VLF})$. Recent improvements in non-linear theories provide additional tools to analyze the entropy domain, better describe complexity, and the non-linear temporal relationships with other metrics such as functional connectivity, and extract information [110-113].

HRV reflects the circadian 24-h cycle with a peak during the second half of the night [114]. Increased HRV during the night relates to the increase in parasympathetic activity, as well as to the interaction between sympathetic and parasympathetic systems [115]. HRV shows a maximal shift toward the sympathetic system during the morning transition from sleep to wakefulness that parallels cortisol peak levels [116]. An increase in heart rate is found around awakening with peak values between 10.00 and 12.00 am (acrophase) and a smaller afternoon peak, after which heart rate begins to decrease to remain lower during the night $[117,118]$. Other cardiovascular parameters such as blood pressure, cardiac output, and catecholamine serum level are also cyclic $[119,120]$. A circadian rhythm comparable to those of heart rate and blood pressure has been observed in the activity of the renin-angiotensin system regulating cardiovascular functions [121,122].

\section{Comments}

A complex and pervasive circadian arrangement governs and modulates brain and body functions, the ANS balance, and the CNS/ANS interaction by complex neural networks and non-neuronal factors which interact with each other and depend on circadian timing [123-126]. Examples in this regard are the sympathetic activation associated with peak cortisol levels in the morning sleep-to-wake transition $[116,127,128]$, and the circadian occurrence of the neurological indices of responsiveness currently used in the classification and prediction of outcome of disorders of consciousness (DoC) [129-133]. The circadian functional arrangement can be disordered by pathologies or temporally disarranged by adaptation to unsuitable conditions, especially if affecting the sleep-wakefulness alternation. Major sleep disorders, inadequate sleeping, and misalignment between human activities and circadian rhythms can result in severe detrimental effects and pathophysiological conditions [63,69,78,80-82,134-136]. CNS and ANS setups change over time, spontaneously (e.g., to 
comply with circadian rhythms) or due to homeostatic or allostatic requirements, with different timing and latencies; the CNS/ANS interaction can change accordingly, but with timing difficult to predict and a relationship with the sleep/wakefulness alternation still to be investigated in full detail. HRV only indirectly provides information about the CNA/ANS function and balance. HRV measures at rest and in response to stimulus conditions, however, have high time resolution and can reflect rapid changes better than clinical or neuroimaging markers of damage, also describing the variability during the day and its correlation with the circadian cycle [131-133,137-140].

\section{Conclusions}

Time and the circadian cycle appear to be sources of variability adding to the variety of environmental factors, and may become crucial when considering the ANS major role in internal environment constancy and adaptation that are fundamental to homeostasis. In contrast with experimental and clinical evidence and the availability of tools for noninvasive measurements ntwithstanding, the CNS/ANS interaction has not yet obtained its deserved attention and systematic investigation remains overdue.

Author Contributions: F.R., V.P., A.S., C.d.P. and W.G.S. equally contributed to the designing, organization, writing, and supervision of this review.

Funding: This research received no external funding.

Conflicts of Interest: The authors declare no conflict of interest.

\section{References}

1. Panda, S.; Hogenesch, J.B.; Kay, S.A. Circadian rhythms from flies to human. Nature 2002, 417, 329-335. [CrossRef] [PubMed]

2. Reppert, S.M.; Weaver, D.R. Coordination of circadian timing in mammals. Nature 2002, 418, 935-941. [CrossRef] [PubMed]

3. Schibler, U.; Ripperger, J.; Brown, S.A. Peripheral Circadian Oscillators in Mammals: Time and Food. J. Biol. Rhythm. 2003, 18, 250-260. [CrossRef] [PubMed]

4. Gillette, M.U.; Tischkau, S.A. Suprachiasmatic nucleus: The brain's circadian clock. Recent Prog. Horm. Res. 1999, 54, 33-58. [PubMed]

5. Kräuchi, K. How is the circadian rhythm of core body temperature regulated? Clin. Auton. Res. 2002, 12, 147-149. [CrossRef] [PubMed]

6. Ivanov, P.C.; Hu, K.; Hilton, M.F.; Shea, S.A.; Stanley, H.E. Endogenous circadian rhythm in human motor activity uncoupled from circadian influences on cardiac dynamics. PNAS 2007, 104, 20702-20707. [CrossRef] [PubMed]

7. Maury, E.; Ramsey, K.M.; Bass, J. Circadian rhythms and metabolic syndrome: From experimental genetics to human disease. Circ. Res. 2010, 106, 447-462. [CrossRef]

8. Konturek, P.C.; Brzozowski, T.; Konturek, S.J. Gut clock: Implication of circadian rhythms in the gastrointestinal tract. J. Physiol. Pharmacol. 2011, 62, 139-150.

9. Hasler, B.P.; Smith, L.J.; Cousins, J.C.; Bootzin, R.R. Circadian rhythms, sleep, and substance abuse. Sleep Med. Rev. 2012, 16, 67-81. [CrossRef]

10. Portaluppi, F.; Tiseo, R.; Smolensky, M.H.; Hermida, R.C.; Ayala, D.E.; Fabbian, F. Circadian rhythms and cardiovascular health. Sleep Med. Rev. 2012, 16, 151-166. [CrossRef]

11. Gamble, K.L.; Berry, R.; Frank, S.J.; Young, M.E. Circadian Clock Control of Endocrine Factors. Nat. Rev. Endocrinol. 2014, 10, 466-475. [CrossRef] [PubMed]

12. Gaggioni, G.; Maquet, P.; Schmidt, C.; Dijk, D.-J.; Vandewalle, G. Neuroimaging, cognition, light and circadian rhythms. Front. Syst. Neurosci. 2014, 8, 8. [CrossRef] [PubMed]

13. Gillette, M.U.; Reppert, S.M. The hypothalamic suprachiasmatic nuclei: Circadian patterns of vasopressin secretion and neuronal activity in vitro. Brain Res. Bull. 1987, 19, 135-139. [CrossRef]

14. Buijs, R.; van Eden, C.; Goncharuk, V.; Kalsbeek, A. The biological clock tunes the organs of the body: Timing by hormones and the autonomic nervous system. J. Endocrinol. 2003, 177, 17-26. [CrossRef] [PubMed] 
15. Buijs, R.M.; Kalsbeek, A. Hypothalamic integration of central and peripheral clocks. Nat. Rev. Neurosci. 2001, 2, 521-526. [CrossRef] [PubMed]

16. Hastings, M.H.; Reddy, A.B.; Maywood, E.S. A clockwork web: Circadian timing in brain and periphery, in health and disease. Nat. Rev. Neurosci. 2003, 4, 649-661. [CrossRef] [PubMed]

17. Kalsbeek, A.; Palm, I.F.; La Fleur, S.E.; Scheer, F.A.J.L.; Perreau-Lenz, S.; Ruiter, M.; Kreier, F.; Cailotto, C.; Buijs, R.M. SCN Outputs and the Hypothalamic Balance of Life. J. Biol. Rhythm. 2006, 21, 458-469. [CrossRef]

18. Buijs, F.N.; León-Mercado, L.; Guzmán-Ruiz, M.; Guerrero-Vargas, N.N.; Romo-Nava, F.; Buijs, R.M. The Circadian System: A Regulatory Feedback Network of Periphery and Brain. Physiology 2016, 31, 170-181. [CrossRef]

19. Astiz, M.; Heyde, I.; Oster, H. Mechanisms of Communication in the Mammalian Circadian Timing System. Int. J. Mol. Sci. 2019, 20, 343. [CrossRef]

20. Kriegsfeld, L.J.; Silver, R. The regulation of neuroendocrine function: Timing is everything. Horm. Behav. 2006, 49, 557-574. [CrossRef]

21. Nitabach, M.N. Circadian rhythms: Clock coordination. Nature 2005, 438, 173-175. [CrossRef] [PubMed]

22. Bass, J. Circadian topology of metabolism. Nature 2012, 491, 348-356. [CrossRef] [PubMed]

23. Karatsoreos, I.N.; Bhagat, S.; Bloss, E.B.; Morrison, J.H.; McEwen, B.S. Disruption of circadian clocks has ramifications for metabolism, brain, and behavior. Proc. Natl. Acad. Sci. USA 2011, 108, 1657-1662. [CrossRef] [PubMed]

24. Thompson, R.H.; Swanson, L.W. Structural characterization of a hypothalamic visceromotor pattern generator network. Brain Res. Rev. 2003, 41, 153-202. [CrossRef]

25. Tentolouris, N.; Tsigos, C.; Perea, D.; Koukou, E.; Kyriaki, D.; Kitsou, E.; Daskas, S.; Daifotis, Z.; Makrilakis, K.; Raptis, S.A.; et al. Differential effects of high-fat and high-carbohydrate isoenergetic meals on cardiac autonomic nervous system activity in lean and obese women. Metab. Clin. Exp. 2003, 52, 1426-1432. [CrossRef]

26. Saper, C.B.; Lu, J.; Chou, T.C.; Gooley, J. The hypothalamic integrator for circadian rhythms. Trends Neurosci. 2005, 28, 152-157. [CrossRef] [PubMed]

27. Wehrens, S.M.T.; Christou, S.; Isherwood, C.; Middleton, B.; Gibbs, M.A.; Archer, S.N.; Skene, D.J.; Johnston, J.D. Meal Timing Regulates the Human Circadian System. Curr. Biol. 2017, 27, 1768-1775.e3. [CrossRef] [PubMed]

28. Sollars, P.J.; Smeraski, C.A.; Kaufman, J.D.; Ogilvie, M.D.; Provencio, I.; Pickard, G.E. Melanopsin and non-melanopsin expressing retinal ganglion cells innervate the hypothalamic suprachiasmatic nucleus. Vis. Neurosci. 2003, 20, 601-610. [CrossRef]

29. Beaulé, C.; Robinson, B.; Lamont, E.W.; Amir, S. Melanopsin in the circadian timing system. J. Mol. Neurosci. 2003, 21, 73-89. [CrossRef]

30. Brown, T.M.; Wynne, J.; Piggins, H.D.; Lucas, R.J. Multiple hypothalamic cell populations encoding distinct visual information. J. Physiol. (Lond.) 2011, 589, 1173-1194. [CrossRef]

31. Engeland, W.C.; Arnhold, M.M. Neural circuitry in the regulation of adrenal corticosterone rhythmicity. Endocrine 2005, 28, 325-332. [CrossRef]

32. Morrison, S.F.; Nakamura, K. Central neural pathways for thermoregulation. Front. Biosci. 2011, 16, 74-104. [CrossRef]

33. Nakamura, K. Central circuitries for body temperature regulation and fever. Am. J. Physiol. Regul. Integr. Comp. Physiol. 2011, 301, R1207-R1228. [CrossRef] [PubMed]

34. Gnocchi, D.; Bruscalupi, G. Circadian Rhythms and Hormonal Homeostasis: Pathophysiological Implications. Biology (Basel) 2017, 6, 10. [CrossRef] [PubMed]

35. Joustra, S.D.; Reijntjes, R.H.; Pereira, A.M.; Lammers, G.J.; Biermasz, N.R.; Thijs, R.D. The Role of the Suprachiasmatic Nucleus in Cardiac Autonomic Control during Sleep. PLoS ONE 2016, 11, e0152390. [CrossRef] [PubMed]

36. Refinetti, R. Comparison of light, food, and temperature as environmental synchronizers of the circadian rhythm of activity in mice. J. Physiol. Sci. 2015, 65, 359-366. [CrossRef] [PubMed]

37. Cassone, V.M.; Chesworth, M.J.; Armstrong, S.M. Entrainment of rat circadian rhythms by daily injection of melatonin depends upon the hypothalamic suprachiasmatic nuclei. Physiol. Behav. 1986, 36, 1111-1121. [CrossRef] 
38. Johnson, R.F.; Moore, R.Y.; Morin, L.P. Loss of entrainment and anatomical plasticity after lesions of the hamster retinohypothalamic tract. Brain Res. 1988, 460, 297-313. [CrossRef]

39. Sherin, J.E.; Shiromani, P.J.; McCarley, R.W.; Saper, C.B. Activation of ventrolateral preoptic neurons during sleep. Science 1996, 271, 216-219. [CrossRef]

40. Gaus, S.E.; Strecker, R.E.; Tate, B.A.; Parker, R.A.; Saper, C.B. Ventrolateral preoptic nucleus contains sleep-active, galaninergic neurons in multiple mammalian species. Neuroscience 2002, 115, 285-294. [CrossRef]

41. Sherin, J.E.; Elmquist, J.K.; Torrealba, F.; Saper, C.B. Innervation of histaminergic tuberomammillary neurons by GABAergic and galaninergic neurons in the ventrolateral preoptic nucleus of the rat. J. Neurosci. 1998, 18, 4705-4721. [CrossRef] [PubMed]

42. Szymusiak, R.; Alam, N.; Steininger, T.L.; McGinty, D. Sleep-waking discharge patterns of ventrolateral preoptic/anterior hypothalamic neurons in rats. Brain Res. 1998, 803, 178-188. [CrossRef]

43. Lu, J.; Bjorkum, A.A.; Xu, M.; Gaus, S.E.; Shiromani, P.J.; Saper, C.B. Selective activation of the extended ventrolateral preoptic nucleus during rapid eye movement sleep. J. Neurosci. 2002, 22, 4568-4576. [CrossRef] [PubMed]

44. Verret, L.; Fort, P.; Luppi, P.H. Localization of the neurons responsible for the inhibition of locus coeruleus noradrenergic neurons during paradoxical sleep in the rat. In Sleep; Amer Academy Sleep Medicine: Westchester, IL, USA, 2003; Volume 26, p. A68.

45. John, J.; Wu, M.-F.; Boehmer, L.N.; Siegel, J.M. Cataplexy-active neurons in the hypothalamus: Implications for the role of histamine in sleep and waking behavior. Neuron 2004, 42, 619-634. [CrossRef]

46. Ko, E.M.; Estabrooke, I.V.; McCarthy, M.; Scammell, T.E. Wake-related activity of tuberomammillary neurons in rats. Brain Res. 2003, 992, 220-226. [CrossRef] [PubMed]

47. Hallanger, A.E.; Levey, A.I.; Lee, H.J.; Rye, D.B.; Wainer, B.H. The origins of cholinergic and other subcortical afferents to the thalamus in the rat. J. Comp. Neurol. 1987, 262, 105-124. [CrossRef] [PubMed]

48. Jones, B.E. Arousal systems. Front. Biosci. 2003, 8, s438-s451. [CrossRef] [PubMed]

49. Saper, C.B.; Cano, G.; Scammell, T.E. Homeostatic, circadian, and emotional regulation of sleep. J. Com. Neurol. 2005, 493, 92-98. [CrossRef]

50. Saper, C.B.; Fuller, P.M.; Pedersen, N.P.; Lu, J.; Scammell, T.E. Sleep State Switching. Neuron 2010, 68, 1023-1042. [CrossRef]

51. Chou, T.C.; Bjorkum, A.A.; Gaus, S.E.; Lu, J.; Scammell, T.E.; Saper, C.B. Afferents to the ventrolateral preoptic nucleus. J. Neurosci. 2002, 22, 977-990. [CrossRef]

52. Chou, T.C.; Scammell, T.E.; Gooley, J.J.; Gaus, S.E.; Saper, C.B.; Lu, J. Critical role of dorsomedial hypothalamic nucleus in a wide range of behavioral circadian rhythms. J. Neurosci. 2003, 23, 10691-10702. [CrossRef] [PubMed]

53. Sakurai, T.; Nagata, R.; Yamanaka, A.; Kawamura, H.; Tsujino, N.; Muraki, Y.; Kageyama, H.; Kunita, S.; Takahashi, S.; Goto, K.; et al. Input of orexin/hypocretin neurons revealed by a genetically encoded tracer in mice. Neuron 2005, 46, 297-308. [CrossRef] [PubMed]

54. Thompson, R.H.; Canteras, N.S.; Swanson, L.W. Organization of projections from the dorsomedial nucleus of the hypothalamus: A PHA-L study in the rat. J. Comp. Neurol. 1996, 376, 143-173. [CrossRef]

55. Lu, J.; Zhang, Y.H.; Chou, T.C.; Gaus, S.E.; Elmquist, J.K.; Shiromani, P.; Saper, C.B. Contrasting effects of ibotenate lesions of the paraventricular nucleus and subparaventricular zone on sleep-wake cycle and temperature regulation. J. Neurosci. 2001, 21, 4864-4874. [CrossRef] [PubMed]

56. Watts, A.G.; Swanson, L.W.; Sanchez-Watts, G. Efferent projections of the suprachiasmatic nucleus: I. Studies using anterograde transport of Phaseolus vulgaris leucoagglutinin in the rat. J. Comp. Neurol. 1987, 258, 204-229. [CrossRef]

57. Aston-Jones, G.; Chen, S.; Zhu, Y.; Oshinsky, M.L. A neural circuit for circadian regulation of arousal. Nat. Neurosci. 2001, 4, 732-738. [CrossRef]

58. Maquet, P. Brain mechanisms of sleep: Contribution of neuroimaging techniques. J. Psychopharmacol. (Oxf.) 1999, 13, S25-S28. [CrossRef]

59. Chamberlin, N.L.; Arrigoni, E.; Chou, T.C.; Scammell, T.E.; Greene, R.W.; Saper, C.B. Effects of adenosine on gabaergic synaptic inputs to identified ventrolateral preoptic neurons. Neuroscience 2003, 119, 913-918. [CrossRef] 
60. Porkka-Heiskanen, T.; Strecker, R.E.; McCarley, R.W. Brain site-specificity of extracellular adenosine concentration changes during sleep deprivation and spontaneous sleep: An in vivo microdialysis study. Neuroscience 2000, 99, 507-517. [CrossRef]

61. Gvilia, I. Underlying brain mechanisms that regulate sleep-wakefulness cycles. Int. Rev. Neurobiol. 2010, 93, $1-21$.

62. Ramsay, D.S.; Woods, S.C. Clarifying the Roles of Homeostasis and Allostasis in Physiological Regulation. Psychol. Rev. 2014, 121, 225-247. [CrossRef] [PubMed]

63. McEwen, B.S. Stress, adaptation, and disease: Allostasis and allostatic load. Ann. N. Y. Acad. Sci. 1998, 840, 33-44. [CrossRef] [PubMed]

64. McEwen, B.S.; Karatsoreos, I.N. Sleep Deprivation and Circadian Disruption: Stress, Allostasis, and Allostatic Load. Sleep Med. Clin. 2015, 10,1-10. [CrossRef] [PubMed]

65. Landgraf, D.; Koch, C.E.; Oster, H. Embryonic development of circadian clocks in the mammalian suprachiasmatic nuclei. Front. Neuroanat. 2014, 8, 143. [CrossRef] [PubMed]

66. Heraghty, J.L.; Hilliard, T.N.; Henderson, A.J.; Fleming, P.J. The physiology of sleep in infants. Arch. Dis. Child. 2008, 93, 982-985. [CrossRef] [PubMed]

67. Hagenauer, M.H.; Perryman, J.I.; Lee, T.M.; Carskadon, M.A. Adolescent Changes in the Homeostatic and Circadian Regulation of Sleep. Dev. Neurosci. 2009, 31, 276-284. [CrossRef] [PubMed]

68. Maywood, E.S.; Mrosovsky, N.; Field, M.D.; Hastings, M.H. Rapid down-regulation of mammalian Period genes during behavioral resetting of the circadian clock. Proc. Natl. Acad. Sci. USA 1999, 96, 15211-15216. [CrossRef] [PubMed]

69. Kondratova, A.A.; Kondratov, R.V. The circadian clock and pathology of the ageing brain. Nat. Rev. Neurosci. 2012, 13, 325-335. [CrossRef]

70. Hunt, N.J.; Rodriguez, M.L.; Waters, K.A.; Machaalani, R. Changes in orexin (hypocretin) neuronal expression with normal aging in the human hypothalamus. Neurobiol. Aging 2015, 36, 292-300. [CrossRef]

71. Yamazaki, S.; Straume, M.; Tei, H.; Sakaki, Y.; Menaker, M.; Block, G.D. Effects of aging on central and peripheral mammalian clocks. Proc. Natl. Acad. Sci. USA 2002, 99, 10801-10806. [CrossRef]

72. Asai, M.; Yoshinobu, Y.; Kaneko, S.; Mori, A.; Nikaido, T.; Moriya, T.; Akiyama, M.; Shibata, S. Circadian profile of Per gene mRNA expression in the suprachiasmatic nucleus, paraventricular nucleus, and pineal body of aged rats. J. Neurosci. Res. 2001, 66, 1133-1139. [CrossRef] [PubMed]

73. Roozendaal, B.; van Gool, W.A.; Swaab, D.F.; Hoogendijk, J.E.; Mirmiran, M. Changes in vasopressin cells of the rat suprachiasmatic nucleus with aging. Brain Res. 1987, 409, 259-264. [CrossRef]

74. Redline, S.; Kirchner, H.L.; Quan, S.F.; Gottlieb, D.J.; Kapur, V.; Newman, A. The effects of age, sex, ethnicity, and sleep-disordered breathing on sleep architecture. Arch. Intern. Med. 2004, 164, 406-418. [CrossRef] [PubMed]

75. Barbosa, A.A.; Miguel, M.A.L.; Tufik, S.; Sabino, F.C.; Cendoroglo, M.S.; Pedrazzoli, M. Sleep disorder or simple sleep ontogeny? Tendency for morningness is associated with worse sleep quality in the elderly. Braz. J. Med. Biol. Res. 2016, 49, e5311. [CrossRef] [PubMed]

76. Carrier, J.; Monk, T.H.; Reynolds, C.F.; Buysse, D.J.; Kupfer, D.J. Are age differences in sleep due to phase differences in the output of the circadian timing system? Chronobiol. Int. 1999, 16, 79-91. [CrossRef] [PubMed]

77. Moraes, W.; Poyares, D.; Rosa, A.; Mello, M.T.; Rueda, A.; Guilleminault, C.; Tufik, S. Overnight weight loss: Relationship with sleep structure and heart rate variability. Available online: http://hdl.handle.net/10101/ npre.2008.2342.1 (accessed on 21 May 2019).

78. Kim, J.H.; Duffy, J.F. Circadian Rhythm Sleep-Wake Disorders in Older Adults. Sleep Med. Clin. 2018, 13, 39-50. [CrossRef]

79. Duffy, J.F.; Dijk, D.J.; Klerman, E.B.; Czeisler, C.A. Later endogenous circadian temperature nadir relative to an earlier wake time in older people. Am. J. Physiol. 1998, 275, R1478-R1487. [CrossRef]

80. Baron, K.G.; Reid, K.J. Circadian misalignment and health. Int. Rev. Psychiatry 2014, 26, 139-154. [CrossRef]

81. Duffy, J.F.; Zitting, K.-M.; Chinoy, E.D. Aging and Circadian Rhythms. Sleep Med. Clin. 2015, 10, $423-434$. [CrossRef]

82. Muller, J.E. Circadian variation in cardiovascular events. Am. J. Hypertens. 1999, 12, 35S-42S. [CrossRef]

83. Thayer, J.F.; Lane, R.D. Claude Bernard and the heart-brain connection: Further elaboration of a model of neurovisceral integration. Neurosci. Biobehav. Rev. 2009, 33, 81-88. [CrossRef] [PubMed] 
84. Maier, S.F.; Goehler, L.E.; Fleshner, M.; Watkins, L.R. The role of the vagus nerve in cytokine-to-brain communication. Ann. N. Y. Acad. Sci. 1998, 840, 289-300. [CrossRef] [PubMed]

85. Pavlov, V.A.; Tracey, K.J. The vagus nerve and the inflammatory reflex-linking immunity and metabolism. Nat. Rev. Endocrinol. 2012, 8, 743-754. [CrossRef] [PubMed]

86. Gabella, G. Autonomic Nervous System. In Els; John Wiley Sons, Ltd.: Hoboken, NJ, USA, 2001; ISBN 978-0-470-01590-2.

87. Badra, L.J.; Cooke, W.H.; Hoag, J.B.; Crossman, A.A.; Kuusela, T.A.; Tahvanainen, K.U.; Eckberg, D.L. Respiratory modulation of human autonomic rhythms. Am. J. Physiol. Heart Circ. Physiol. 2001, 280, H2674-H2688. [CrossRef] [PubMed]

88. Bentley, M.T.; Paolone, V.J. Heart rate variability and thermoregulation during resting cold-water immersion and upper body exercise. Med. Sci. Sports Exerc. 2003, 35, S254. [CrossRef]

89. Bonsignore, M.R. Baroreflex control of heart rate during sleep in severe obstructive sleep apnoea: Effects of acute CPAP. Eur. Respir. J. 2006, 27, 128-135. [CrossRef]

90. Riganello, F.; Dolce, G.; Sannita, W. Heart rate variability and the central autonomic network in the severe disorder of consciousness. J. Rehabil. Med. 2012, 44, 495-501. [CrossRef]

91. Berntson, G.G.; Cacioppo, J.T. Heart rate variability: Stress and psychiatric conditions. Dyn. Electrocar. 2004, 57-64. [CrossRef]

92. Friedman, B.H. An autonomic flexibility-neurovisceral integration model of anxiety and cardiac vagal tone. Biol. Psychol. 2007, 74, 185-199. [CrossRef]

93. Hagemann, D.; Waldstein, S.R.; Thayer, J.F. Central and autonomic nervous system integration in emotion. Brain Cogn. 2003, 52, 79-87. [CrossRef]

94. Riganello, F. Responsiveness and the Autonomic Control-CNS Two-Way Interaction in Disorders of Consciousness. In Brain Function and Responsiveness in Disorders of Consciousness; Monti, M.M., Sannita, W.G., Eds.; Springer International Publishing: Cham, Switzerland, 2016; pp. 145-155. ISBN 978-3-319-21424-5.

95. Thayer, J.F.; Sternberg, E. Beyond Heart Rate Variability. Ann. N. Y. Acad. Sci. 2006, 1088, 361-372. [CrossRef] [PubMed]

96. Benarroch, E.E. Enteric nervous system Functional organization and neurologic implications. Neurology 2007, 69, 1953-1957. [CrossRef] [PubMed]

97. Napadow, V.; Dhond, R.; Conti, G.; Makris, N.; Brown, E.N.; Barbieri, R. Brain Correlates of Autonomic Modulation: Combining Heart Rate Variability with fMRI. Neuroimage 2008, 42, 169-177. [CrossRef] [PubMed]

98. Benarroch, E.E. The Central Autonomic Network: Functional Organization, Dysfunction, and Perspective. Mayo Clin. Proc. 1993, 68, 988-1001. [CrossRef]

99. Benarroch, E.; Singer, W.; Mauermann, M. Autonomic Neurology; Oxford University Press: Oxford, UK, 2014; ISBN 978-0-19-992019-8.

100. Bandler, R.; Keay, K.A.; Floyd, N.; Price, J. Central circuits mediating patterned autonomic activity during active vs. passive emotional coping. Brain Res. Bull. 2000, 53, 95-104. [CrossRef]

101. Barbas, H.; Saha, S.; Rempel-Clower, N.; Ghashghaei, T. Serial pathways from primate prefrontal cortex to autonomic areas may influence emotional expression. BMC Neurosci. 2003, 4, 25. [CrossRef] [PubMed]

102. Hsu, D.T.; Price, J.L. Midline and intralaminar thalamic connections with the orbital and medial prefrontal networks in macaque monkeys. J. Comp. Neurol. 2007, 504, 89-111. [CrossRef] [PubMed]

103. Thayer, J.F.; Åhs, F.; Fredrikson, M.; Sollers, J.J.; Wager, T.D. A meta-analysis of heart rate variability and neuroimaging studies: Implications for heart rate variability as a marker of stress and health. Neurosci. Biobehav. Rev. 2012, 36, 747-756. [CrossRef]

104. Appelhans, B.M.; Luecken, L.J. Heart rate variability as an index of regulated emotional responding. Rev. Gen. Psychol. 2006, 10, 229-240. [CrossRef]

105. Frazier, T.W.; Strauss, M.E.; Steinhauer, S.R. Respiratory sinus arrhythmia as an index of emotional response in young adults. Psychophysiology 2004, 41, 75-83. [CrossRef]

106. Mashin, V.A.; Mashina, M.N. Analysis of the heart rate variability in negative functional states in the course of psychological relaxation sessions. Hum. Physiol. 2000, 26, 420-425. [CrossRef]

107. Nickel, P.; Nachreiner, F. Sensitivity and Diagnosticity of the 0.1-Hz Component of Heart Rate Variability as an Indicator of Mental Workload. Hum. Factors: J. Hum. Factors Ergon. Soc. 2003, 45, 575-590. [CrossRef] [PubMed] 
108. Ernst, G. Heart-Rate Variability-More than Heart Beats? Front. Public Health 2017, 5, 240. [CrossRef] [PubMed]

109. Task Force of the European Society of Cardiology and the North American Society of Pacing and Electrophysiology Heart rate variability: Standards of measurement, physiological interpretation and clinical use. Circulation 1996, 93, 1043-1065. [CrossRef]

110. Norris, P.R.; Ozdas, A.; Cao, H.; Williams, A.E.; Harrell, F.E.; Jenkins, J.M.; Morris, J.A., Jr. Cardiac uncoupling and heart rate variability stratify ICU patients by mortality: A study of 2088 trauma patients. Ann. Surg. 2006, 243, 804-812. [CrossRef]

111. Riganello, F.; Larroque, S.K.; Bahri, M.A.; Heine, L.; Martial, C.; Carrière, M.; Charland-Verville, V.; Aubinet, C.; Vanhaudenhuyse, A.; Chatelle, C.; et al. A Heartbeat Away from Consciousness: Heart Rate Variability Entropy Can Discriminate Disorders of Consciousness and Is Correlated With Resting-State fMRI Brain Connectivity of the Central Autonomic Network. Front. Neurol. 2018, 9, 769. [CrossRef]

112. Ryan, M.L.; Thorson, C.M.; Otero, C.A.; Vu, T.; Proctor, K.G. Clinical Applications of Heart Rate Variability in the Triage and Assessment of Traumatically Injured Patients. Anesthesiol. Res. Pract. 2011, 2011, 8. [CrossRef]

113. Shaffer, F.; McCraty, R.; Zerr, C.L. A healthy heart is not a metronome: An integrative review of the heart's anatomy and heart rate variability. Front. Psychol. 2014, 5, 1040. [CrossRef]

114. Massin, M.M.; Maeyns, K.; Withofs, N.; Ravet, F.; Gérard, P. Circadian rhythm of heart rate and heart rate variability. Arch. Dis. Child. 2000, 83, 179-182. [CrossRef]

115. Sammito, S.; Sammito, W.; Böckelmann, I. The circadian rhythm of heart rate variability. Biol. Rhythm Res. 2016, 47, 717-730. [CrossRef]

116. Boudreau, P.; Yeh, W.H.; Dumont, G.A.; Boivin, D.B. A circadian rhythm in heart rate variability contributes to the increased cardiac sympathovagal response to awakening in the morning. Chronobiol. Int. 2012, 29, 757-768. [CrossRef] [PubMed]

117. Guo, Y.-F.; Stein, P.K. Circadian rhythm in the cardiovascular system: Chronocardiology. Am. Heart J. 2003, 145, 779-786. [CrossRef]

118. Yamasaki, Y.; Kodama, M.; Matsuhisa, M.; Kishimoto, M.; Ozaki, H.; Tani, A.; Ueda, N.; Ishida, Y.; Kamada, T. Diurnal heart rate variability in healthy subjects: Effects of aging and sex difference. Am. J. Physiol. 1996, 271, H303-H310. [CrossRef] [PubMed]

119. Kapiotis, S.; Jilma, B.; Quehenberger, P.; Ruzicka, K.; Handler, S.; Speiser, W. Morning hypercoagulability and hypofibrinolysis. Diurnal variations in circulating activated factor VII, prothrombin fragment F1+2, and plasmin-plasmin inhibitor complex. Circulation 1997, 96, 19-21. [CrossRef] [PubMed]

120. Veerman Derk, P.; Imholz Ben, P.M.; Wieling, W.; Wesseling Karel, H.; van Montfrans Gert, A. Circadian Profile of Systemic Hemodynamics. Hypertension 1995, 26, 55-59. [CrossRef]

121. Cugini, P.; Halberg, F.; Sothern, R.B.; Centanni, M.; Salandi, E.; Scavo, D. Sodium restriction amplifies and propranolol loading inhibits circadian rhythm of plasma renin-angiotensin and aldosterone. Chronobiologia 1985, 12, 155-165. [PubMed]

122. Kawasaki, T.; Uezono, K.; Ueno, M.; Omae, T.; Matsuoka, M.; Haus, E.; Halberg, F. Comparison of circadian rhythms of the renin-angiotensin-aldosterone system and electrolytes in clinically healthy young women in Fukuoka (Japan) and Minnesota (USA). Acta. Endocrinol. 1983, 102, 246-251. [CrossRef]

123. Bullock, T.H. The Reliability of Neurons. J. Gen. Physiol. 1970, 55, 565-584. [CrossRef]

124. Sannita, W.G. Individual variability, end-point effects and possible biases in electrophysiological research. Clin. Neurophysiol. 2006, 117, 2569-2583. [CrossRef]

125. Garbarino, S.; Lanteri, P.; Feeling, N.R.; Jarczok, M.N.; Quintana, D.S.; Koenig, J.; Sannita, W.G. Circadian Rhythms, Sleep, and the Autonomic Nervous System: A Position Paper. J. Psychophysiol. 2019, 33, 1-9. [CrossRef]

126. Soddu, A.; Bassetti, C.L. A good sleep for a fresh mind in patients with acute traumatic brain injury. Neurology 2017, 88, 226-227. [CrossRef] [PubMed]

127. Bilan, A.; Witczak, A.; Palusiński, R.; Myśliński, W.; Hanzlik, J. Circadian rhythm of spectral indices of heart rate variability in healthy subjects. J. Electrocardiol. 2005, 38, 239-243. [CrossRef] [PubMed]

128. Boudreau, P.; Dumont, G.; Kin, N.K.N.Y.; Walker, C.-D.; Boivin, D.B. Correlation of Heart Rate Variability and Circadian Markers in Humans. In Proceedings of the 2011 Annual International Conference of the IEEE Engineering in Medicine and Biology Society, Boston, MA, USA, 30 August-3 September 2011; pp. 681-682.

129. Giacino, J.T.; Ashwal, S.; Childs, N.; Cranford, R.; Jennett, B.; Katz, D.I.; Kelly, J.P.; Rosenberg, J.H.; Whyte, J.; Zafonte, R.D.; et al. The minimally conscious state: Definition and diagnostic criteria. Neurology 2002, 58, 349-353. [CrossRef] [PubMed] 
130. Laureys, S.; Celesia, G.G.; Cohadon, F.; Lavrijsen, J.; León-Carrión, J.; Sannita, W.G.; Sazbon, L.; Schmutzhard, E.; von Wild, K.R.; Zeman, A.; et al. Unresponsive wakefulness syndrome: A new name for the vegetative state or apallic syndrome. BMC Med. 2010, 8, 68. [CrossRef] [PubMed]

131. Candelieri, A.; Cortese, M.D.; Dolce, G.; Riganello, F.; Sannita, W.G. Visual Pursuit: Within-Day Variability in the Severe Disorder of Consciousness. J. Neurotrauma 2011, 28, 2013-2017. [CrossRef]

132. Riganello, F.; Cortese, M.D.; Dolce, G.; Lucca, L.F.; Sannita, W.G. The Autonomic System Functional State Predicts Responsiveness in Disorder of Consciousness. J. Neurotrauma 2015, 32, 1071-1077. [CrossRef]

133. Sannita, W.G. Responsiveness in DoC and individual variability. Front. Hum. Neurosci. 2015, 9, 270. [CrossRef]

134. Aziz, N.A.; Anguelova, G.V.; Marinus, J.; Lammers, G.J.; Roos, R.A.C. Sleep and circadian rhythm alterations correlate with depression and cognitive impairment in Huntington's disease. Parkinsonism Relat. Disord. 2010, 16, 345-350. [CrossRef]

135. Garbarino, S.; Sannita, W.G.; Falkenstein, M. Inadequate Sleeping Impairs Brain Function and Aggravates Everyday's Life: A Challenge for Human Psychophysiology? J. Psychophysiol. 2017, 31, 91-93. [CrossRef]

136. Shen, D.; Cui, L.; Shen, Z.; Garbarino, S.; Sannita, W.G.; Hannawi, Y.; Stevens, R.D. Resting brain activity in disorders of consciousness: A systematic review and meta-analysis. Neurology 2016, 86, 200-201. [CrossRef]

137. Abbate, C.; Trimarchi, P.D.; Basile, I.; Mazzucchi, A.; Devalle, G. Sensory stimulation for patients with disorders of consciousness: From stimulation to rehabilitation. Front. Hum. Neurosci. 2014, 8, 616. [CrossRef] [PubMed]

138. Bekinschtein, T.A.; Golombek, D.A.; Simonetta, S.H.; Coleman, M.R.; Manes, F.F. Circadian rhythms in the vegetative state. Brain Inj. 2009, 23, 915-919. [CrossRef] [PubMed]

139. Blume, C.; Lechinger, J.; Santhi, N.; del Giudice, R.; Gnjezda, M.-T.; Pichler, G.; Scarpatetti, M.; Donis, J.; Michitsch, G.; Schabus, M. Significance of circadian rhythms in severely brain-injured patients: A clue to consciousness? Neurology 2017, 88, 1933-1941. [CrossRef] [PubMed]

140. Riganello, F.; Cortese, M.D.; Dolce, G.; Sannita, W.G. Visual pursuit response in the severe disorder of consciousness: Modulation by the central autonomic system and a predictive model. BMC Neurol. 2013, 13, 164. [CrossRef] [PubMed] 